\title{
On the Awakening of Female Consciousness in It Happened One Night
}

\author{
Shuo Yao \\ Guangdong University of Foreign Studies, Guangzhou, China
}

\begin{abstract}
In the 1930s, the United States was at the beginning of the Great Depression, while at the same time its film industry was booming. The screwball comedy as a new type of film became popular. One of the most representative and successful screwball comedies, It Happened One Night by Frank Capra in 1934, which not only won five awards of the Seventh Oscar, but also saved the Columbia Pictures from bankruptcy, can be called a miracle in the history of American film. As a pioneering work of the screwball comedy, the film's theme, narrative and other aspects have exerted profound influences on the subsequent films of this kind. Among the many advantages of this film, it is worth noting that the image of the heroine breaks people's traditional idea about women, which is ahead of its time. Besides, we can see her gradual awakening of female consciousness. Therefore, combining with the social and historical background at that time and the characteristics of the screwball comedy, this paper attempts to reveal the female image of the heroine Ellie and give a general view of the course of her consciousness awakening by analyzing lens language of the film, including shots, lighting and sound, together with the narrative.
\end{abstract}

Index Terms - screwball comedy, awakening of female consciousness, lens language, It Happened One Night

\section{INTRODUCTION}

The film It Happened One Night, first released in 1934, was directed by one of the most famous directors of the United States Frank Capra. And the script of it was adapted by his partner Robert Riskin from the love story The Midnight Bus (Li, 2015). The story goes like this: Ellie Andrews, a young and beautiful rich girl who runs away from home in order to get rid of her father's detective, takes a shuttle bus to New York to get married with her lover King Westley. On the bus, she meets Peter Warne, a newly unemployed but optimistic journalist (Wan, 2011). They spend five days and four nights together, and are attracted to each other, then finally fall in love with each other. But due to some misunderstandings, Ellie decides to go back home and marry the person King Westley as planned. Under the help of her father, they clear the misunderstandings up and are reconciled. At the end of the film, Ellie escapes the marriage and lives with Peter (Meng, 2015).

In the current view, the plots seem to be old and out-of date, but it was then very creative and departing from the conventional pattern ( $\mathrm{Li}, 2015)$, which can be proved by the five awards it won in the Seventh Oscar. It was awarded the winner of the Best Picture Oscar; its director Frank Capra won his first Oscar Best Director Award, making a name for himself (Zhao, 1997); its leading actor Clark Gable won the Oscar Award for Best Actor for his outstanding performance in the film, which catapulted him from a second-tier actor to a Hollywood A-list actor (Li, 2015); the leading actress Claudette Colbert also won the Best Actress by virtue of this film, and this film changed her previous stereotyped role image. What's more, the film won the Best Adapted Screenplay, which was attributed to the cooperation between the director and the screenwriter. Moreover, the perfect cooperation between Frank Capra and Robert Riskin became the first example between director and screenwriter in Hollywood (Jun, 2009). Last but not least, it saved Columbia Pictures from bankruptcy that was caused by the downturn and catapulted it into the top tier of film studios (Wu, 2020).

Many scenes in the film, such as drapes hanging in the middle of the room to separate the hero and the heroin from each other, have had profound influences on the following films ( $\mathrm{Li}, 2015)$. It was the paradigm for the screwball comedy of the classic Hollywood era (Liu, 2017). The female image of its heroine also challenged the passive, weak and submissive position of women in the traditional love films, showing gradual awakening of female consciousness, which was ahead of its time (Yue, 2020). Therefore, in the following sections, the paper will focus on the female image of the heroine Ellie and the process of her consciousness awakening in the light of the analysis of the film's narrative and lens language, including shots, lighting and sound (Zhang, 2021), combining with the social and historical background at that time with the characteristics of classic Hollywood screwball comedy.

\section{The Female IMAge OF ELLIE}

Screwball comedy, which was born during the Great Depression in the early 1930s, is one of the most important genre films in the classic Hollywood era (Fan, 2012). Screwball is a term originally used by pitchers in baseball who throw a screwball that deviates from the normal curve ball. In the United States, screwball is also used to refer to people who behave strangely or slightly neurotic in real life (Feng, 2010). 
The classic narrative model of screwball comedy is a love story of a couple of hero and heroine, usually with vastly different status. One of them belongs to the bourgeoisie who is rich enough to do everything and the other is an ordinary person who has little money. At first these two people meet each other by some incidents followed by some conflicts, and then the conflicts will be resolved. The man and the woman will find that they fall in love with each other; therefore, finally they get together (Zhang, 2017). It's worth noting that in the screwball comedy heroines are usually the ones with the higher status. For example, in It Happened One Night, the heroine is a rich girl, in Roman Holiday the heroine is a princess (Zhang and Shi, 2018) and the heroine in Notting Hill is a superstar (Chen, 2013). This is designed to strengthen the conflict between the hero and the heroine, making the heroine strong enough to confront the hero (Feng, 2010). Therefore, they are usually strong in character (Mei, 1999), which breaks the traditional stereotype of submissive, passive and independent women. This kind of female image is also shown through a large number of dialogues in the film, which is another feature of the screwball comedy. One the one hand, the large number of dialogues comes out to meet the trend of films with sound (Zhou, 1984). The rapid quarrels between the hero and the heroine and the witty sarcasm can satisfy the audience's curiosity about the new technology of sound, making the audience feel interested and shocked; on the other hand, through the dialogues and quarrels between the hero and heroine of different social classes, the audience's dissatisfaction in the reality of the economic crisis is also vented (Feng, 2010).

In the classic Hollywood films, the female images of the screwball comedy are very eye-catching. Their prominent status, strong character and bold behavior do not conform to the traditional value and the female stereotype. This is exactly the case with Ellie's female image in the film. At first, she was born in the bourgeoisie, and her father was wealthy enough to buy a cruise ship, hire many servants and detectives, take a private jet and publish notices on newspapers and radio stations for looking for her. These can all show that she has a good family background and financial condition. Moreover, Ellie did not listen to her father's advice. After being slapped in a quarrel with him, she resolutely jumped into the sea to escape, to find her lover and get married, which can show her strong character. After that, she went to New York alone, on the way she met Peter and lived with him in the same room. After discovering that Peter was a reporter, she made a deal with him to let him help to find her lover, and finally they arrived in New York, but she escaped marriage. All of these reflect her bold behavior, proving that she is not a person of rules and regulations, and she is totally different from the traditional female image. In the process of running away from home and looking for the lover, she meets Peter, gets to know him, hates him and falls in love with him. What we can see is an independent, audacious woman who pursues freedom and love. Also, in this process, her female consciousness is gradually awakening.

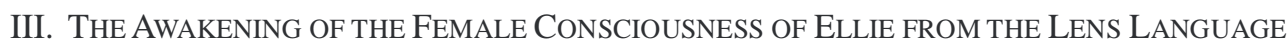

\section{A. The Oppression on Ellie}

Although the heroine Ellie in It Happened One Night has rich family, strong characters and is bold in deeds, we can still see that she is oppressed under such an affluent environment, and this oppression mainly comes from her father.

The first scene of the film was on a luxury cruise. Ellie's father asks her servant about her hunger strike and blames the servant with "Why don't you jam it down her throat?". After that, with a wipe, the shot shifts us to a medium long shot with a straight-on angle. Here the space has changed to Ellie's room. At this point, her father is trying to persuade Ellie to eat. He tells her, "You know I have my way," which shows that the he has always used some means to control her. After Ellie retorts that "Not this time you won't", his speech speed suddenly accelerates, which reflects his oppression in language. And he also indicates that he would never let her be with King Wesley. When he says these words, at the same time, the oppression turns stronger as the camera zooms in to show a middle shot. He is pointing his finger at Ellie while speaking faster to show his opposition. Followed by that is a medium long shot with Ellie walking back and forth in the room, complaining that he has told her what she got to do since she got remember. When Ellie refuses to eat and knocks over all the food, her father finally slaps her face. The shot switches to a medium close-up and quickly cuts between Ellie and her father, showing the subtle expressions on their faces.

In addition, after Ellie jumps into the sea to escape, the father immediately asks servants to write to the detective agency, telling them that his daughter has run away again, and asking them to keep a close eye on all the roads, airports and train stations in Miami. From this, it can be seen that this is not the first time he asks people to do this, showing his strong desire for controlling Ellie.

Furthermore, from Ellie's conversation with Peter, we can get more information about her father's oppression on her. She has never been with a man alone. Whenever and wherever she goes, the nanny, bodyguards, even detectives will follow her, which makes her feel depressed. But she has got used to growing under such an environment. This suggests that she is kind of numb with all these oppressions. The only time when she goes shopping without a bodyguard ends in getting into King Wesley's car to escape capture. And it is in this only time that she considers she finds her true love. In fact, it is her father's control and oppression on her results in her lack of life experience and gullibility, so much so that when she meets a man, she thinks it is true love.

\section{B. The Female Consciousness Awakening in the Bud}

Although Ellie grows up under the control of her father, and gradually gets used to his all-around control, as a person with independent personality, she goes through a process from instinctively resisting such control of her father at the 
beginning, to completely deciding her love and marriage by herself.

As what Ellie tells Peter in the film, she has an instinctive resistance to her father's control at an early time. However, this is just out of instinct and can only be called the female consciousness awakening in the bud. When she makes complaints and tells her escape story to Peter, the shot shifts to focus on Ellie and the table with a medium close-up. We can see clearly her subtle facial expression changes when she is eating breakfast and telling these experiences. It can be seen that she tells the story as a joke to others, and that her brief relief is something great to her. It is during this escape that she thinks she meets her true lover King Wesley, and then she decides to run away to meet him. This actually is consistent with what her father says - she runs away just to disobey her father, not really for the pursuit of love and freedom.

Back to the medium close-up shot in which Ellie is arguing with her father, we can see that not only her father, but also she herself is accelerating the speech speed and raising the voice. Our attention is attracted to their quick conversation and their facial expressions. Obviously, Ellie is impatient, uses "definitely", "legally" and "actually" to tell her father that she and Wesley are married, and rolls her eyes when she informs these to her father. It seems like Ellie has her own idea, but from her father's response, this is just the way she is showing her disagreement with him. Ellie's facial expression when talking with her father, walking around the room impatiently, smoking, as well as the volume, speed and wording, indicate that her quarrel with her father and the escape this time are just out of instinct to get rid of her father's control. To a certain extent, this proves the germination of her awakening of female consciousness.

\section{Further Awakening of Female Consciousness}

During the five days together, she gradually gets fond of Peter. With his help all the way, finally they're only three hours away from New York, but Ellie insists on a night's rest. The camera cuts to the room, where Ellie is sitting on her bed getting dressed while she faces a "wall", which is a drape used to separate them. At this present, the main light comes from the bedside lamp on her right, reflecting her upper body and the "wall". Behind the wall, there is the shadow of Peter who is standing and changing clothes. When she asks Peter when they can see each other again, her speech speed of slows down and her voice is weakened. With the dim light in this tiny room, there is sharp contrast of their poses, one standing and one sitting, one strong and one weak, clearly showing Ellie's reluctance to separate and hesitation. She does not fully realize that she has fallen in love with Peter, but the subsequent dialogue makes her more aware of her feelings for Peter. The camera then tracks in from the whole room to Ellie's side again, with a medium long shot, to the front left of Ellie. The Hollywood classic three-point lighting is used. The main light comes from the right side of the camera, showing Ellie's left body. We can clearly see the expression on her face when she speaks; the filling light comes from the right side of Ellie and is used to show the right side of her body and the background behind it; the backlight comes from the back of Ellie's body and is used to show the bed and the curtains behind it. After listening to Peter's plan, she walks to the other side of the wall from her side and the shot is shifted to a medium close-up shot. In the screen, there are only Ellie and a small part of the upper part of the "wall". The light turns to soft light (Xie, 2017) and we can see that Ellie's eyes are full of tears. With the effect of soft light, she looks delicate and pathetic.

The next second the camera tracks her back to Peter's bed, and she leans over his bed and tells him that she hopes to join him in his plan. In fact, it is a hint or even an expression of her feelings for Peter. In this medium close-up shot, she changes her usual patronizing attitude, falls on the side of the bed, and looks up at Peter. This shows that love changes her from the strong side to the relatively weak side in this relationship, although we can only see her back, but from the dialogue and Peter's facial expressions, we know that he is surprised that Ellie should love him. During their conversation, the camera tracks in from the medium long shot to the medium close-up shot. We can clearly see the confusion on Peter's face. When Peter tells her to go back to her bed, Ellie even speaks in a supplicatory tone that she loves him and can't live without him. What's more, she even wants to run away with Peter instead of going to New York. It can be seen from this that Ellie thinks she has found her true love again. Her female consciousness is further awakening, but at this time, she still chooses to elope. She gives up her former lover easily just because she gets along with Peter for five days. In fact, it seems that she is still trying to escape from her previous life, instead of being truly independent, having her own ideas, and pursuing freedom and love. This can be seen from the later episodes.

After Peter goes at midnight to look for money and petrol, Ellie is driven out of the hotel and thinks that Peter has abandoned her. At this time, she is dismayed and calls her father to take her home and marry King Wesley. Here we can see her love to Peter is so fragile that she doesn't need to confirm what really happens before going back home. Although her father tries to persuade her to cancel the wedding after knowing her story with Peter, she decides to give up for the reason that it will get all the people in trouble and make people laugh at their wedding cancellation. This on the one hand shows that she is mature, on the other hand indicates that her female consciousness is still not fully awakened. Because she abandons herself when thinking that Peter doesn't love her and gives up the so-called restraint and oppression of resistance.

\section{Full Awakening of Female Consciousness}

Their misunderstandings are finally resolved by Ellie's father. At the last moment of the wedding, when Ellie's father walks to the priest arm in arm with her, he encourages her to escape the marriage and find Peter if she wants to. The atmosphere is nervous when they say the vows, but Ellie still doesn't say "I will" and runs away from the wedding. The camera pans as Ellie runs from the wedding to the road and the car. There the long shot shows the whole chaotic scene, 
the guests, reporters and servants all run after her, without more details of their faces. This scene shows that Ellie's female consciousness is completely awakened, and she decides to pursue her love and live the life she wants to at the risk of being blamed and ridiculed by the public and media reporters.

\section{CONCLUSION}

Throughout the film, we can see the classic screwball comedy female image of Ellie. She is strong in character, she is not timid at all when talking with hero, and her behaviors are bold. We can also see in behind her image, that her female consciousness is gradually awakening. At the beginning, she escapes just by instinct against his father's control to pursue the so-called love. Gradually, she falls in love with Peter and is brave enough to show her love and weakness to him, even though she used to be so proud. But for pursuing love and controlling her life, she can do all including escaping marriage. These experiences not only make her mature and independent, but also awaken her female consciousness. This process of gradual awakening of female consciousness can still impact on the contemporary women, who should try to control their own life and pursue their love.

\section{REFERENCES}

[1] Chen Lin. (2013). A brief analysis of female images in the film Notting Hill. Film Literature (20), 104-105.

[2] Fan Yufei. (2012). A brief analysis of the film development in the classic Hollywood period. Journal of Handan Polytechnic College, 25(01), 50-52.

[3] Feng Xin. (2010). Gender comedy as an ideological battlefield -- A study of Hollywood screwball comedy. Journal of Beijing Film Academy, (02), 65-71.

[4] Jun Bing. (2009). The cinematic art world of Frank Capra - the king of comedy in old Hollywood. Young Writers (Chinese and Foreign Literary Edition), (01), 31-33.

[5] Li Qionghua. (2015). Ethical exploration of It Happen One Night from the perspective of escape pursuit. Film literature, (01), 147-149.

[6] Liu Yongxin. (2017). A study on the typology of Hollywood films. Film literature, (02), 33-35.

[7] Mei Feng. (1999). It Happened One Night: A Peep in a Place of Public Life.” Journal of Beijing Film Academy, (01), 89-90.

[8] Meng Haixia. (2015). On the evolution of Cinderella plot pattern in Hollywood love movies. Movie Review, (07), 59-60.

[9] Wan Kexin. (2011). Conflicts and connections between scenes -- Take the Oscar-winning film It Happened One Night as an example. Young Reporters, (35), 64-65.

[10] Wu Peiyu. (2020). An analysis of the similarities and differences between It Happens One Night and Roman Holiday. Media Forum, 03(21), 142+144

[11] Xie Xiaoting. (2017). An analysis of montage theory in It Happen One Night. The Home of the Drama, (03), 123-124.

[12] Yue Yang. (2020). The representation of female consciousness in the early film medium. Popular Literature, (09), 186-187.

[13] Zhang Chu. (2017). A brief analysis of gender politics in neurocomedy and chick movies. Journalism Research Guide, 08(18), $154+169$.

[14] Zhang Wenwen. (2021). A brief analysis of cinematic space narration from the perspective of female consciousness -- taking Letter from an Unknown Woman as an example. The Home of the Drama, (08), 129-130.

[15] Zhang Xiaonan, Shi Zhiyan. (2018). Roman Holiday to Notting Hill: Female Awakening. Film literature, (11), 149-151.

[16] Zhao Wuping. (1997). The Oscars' Age of Capra. Popular Cinema, (05), 28-29.

[17] Zhou Chuanji. (1984). The formation and evolution of sound film. Journal of Beijing Film Academy, (01), 38-59.

Shuo Yao is a postgraduate in Guangdong University of Foreign Studies. Her research field covers second language acquisition. 